


\section{FINE STRUCTURE IN THERMAL GROWTH \\ PATTERNS OF BACTERIA BY \\ MICROCALORIMETRY}

B. R. Staples, E. J. Prosen and R. N. Goldberg

Thermochemistry Section

Physical Chemistry Division

Institute for Materials Research

National Bureau of Standards

Washington, D. C. 20234

April 1973

Interim Report

This report presents results of a preliminary study. This report is to be superseded by a future publication which will receive general distribution and should be cited as a reference. Please consult the NBS Office of Technical Information and Publications to obtain the proper citation.

\section{Prepared for}

National Institute of General Medical Sciences

National Institutes of Health

Bethesda, Maryland 20014

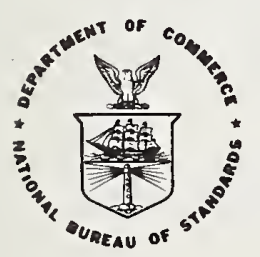

U. S. DEPARTMENT OF COMMERCE, Frederick B. Dent, Secretary NATIONAL BUREAU OF STANDARDS, Richard W. Roberts, Director 



\section{Foreword}

The use of clinical laboratory tests of physiological fluids for specific components has been rapidly increasing in the past few years. One aspect of this has been an increase in the number of tests for we11-known particular substances for which satisfactory tests are available. Another equally important aspect is the increasing need of the physician and of the research biochemist for ready methods for determining other substances present in varying amounts in normal and pathological states. For this reason, the development of new techniques applicable to problems for which optimum solutions have not been found are of considerable interest in clinical and biological chemistry.

The universal occurrence of energy changes in chemical and physiological processes has caused the calorimeter to be considered as a potential tool for clinical chemical analysis and for observing biological processes for some years. The actual applicability, however, has been limited previously by lack or insufficiency of one or more necessary factors. Such factors include: instrument sensitivity and operational noise levels, instruments adapted to use of small samples, simplicity of instrumental operation and data reduction, and suitable mechanisms for sorting out specific processes from a melange of potential interferences. It was the judgment of the authors and of the National Institute of General Medical Sciences (NIGMS) that the understanding of these factors had developed to a point where a well coordinated attack on the application of microcalorimetry would now lead to successful results.

A program was established in the Thermochemistry Section (Physical Chemistry Division, Institute of Materials Research) at the National Bureau of Standards, and after some months was augmented with support from the NIGMS to demonstrate the feasibility of microcalorimetry in some specific areas useful in the Clinical Chemistry Laboratory. Dr. Robert S. Melville is the program officer for NIGMS. Collaborative support has been provided by the Clinical Chemistry Service (Dr. Donald Young, Chief), and by the Laboratory for Technical Development (Dr. Robert L. Bowman, Chief, and Dr. Robert L. Berger).

This is a report provided at the end of the first year of the NIGMS support of this work and summarizes a portion of the 

work done. This report is one of four covering different aspects of the NBS Program. For the information of the reader, the titles and NBS Report numbers of the four reports are as follows:

NBS Report

73-178 Microcalorimetric Assay for Glucose in Human Serum and Plasma

73-179 Design and Construction of the NBS Clinical Microcalorimeter

73-180 Testing of the NBS Clinical Microcalorimeter

73-181 Fine Structure in Thermal Growth Patterns of Bacteria by Microcalorimetry

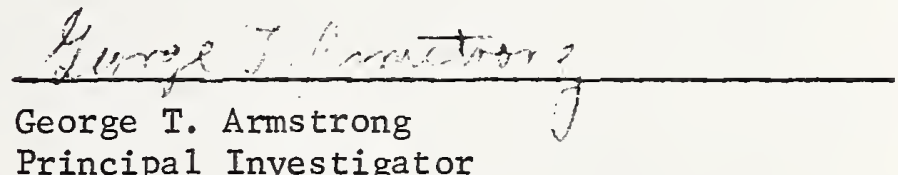

Principal Investigator

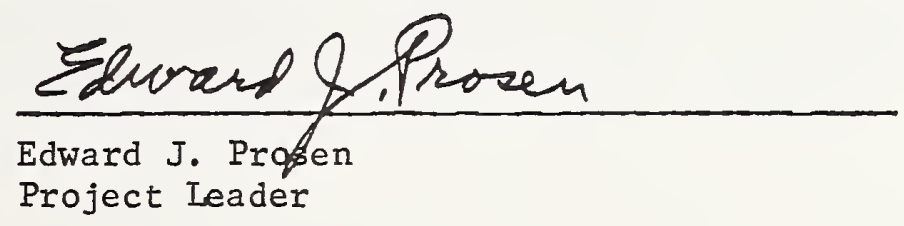



Fine Structure in Therma1 Growth Patterns

of Bacteria by Microcalorimetry

by

B. R. Staples, E. J. Prosen, and R. N. Goldberg

Abstract

Thermal growth patterns of Enterobacter cloacae, Proteus rettgeri, and Klebsiella pneumoniae have been determined with the new NBS CIInical Microcalorimeter. These patterns show more fine structure than those made by previous calorimeters. This is due to the much faster time constant (half-time 30 seconds), the use of smaller volumes $(0.4 \mathrm{ml})$ or thicknesses $(2.5 \mathrm{~mm})$ of samples, and the high sensitivity of the NBS Microcalorimeter. Furthermore, this fine structure is shown to be reproducible and thus is valuable for finer bacterial "fingerprinting" or identification than was previously available. The simplicity of the apparatus and the ease of insertion of samples and operation of the calorimeter make this method attractive for possible routine use in detection and identification of bacteria. 



\section{Introduction}

There are several possible applications of microcalorimetry to probe microbial systems. One may study the metabolic pathway of a microorganism over its lifespan, the thermal patterns of growth can be used to identify the type of bacteria, the effect of medicinal agents on the bacteria can be studied, and perhaps the enthalpy of specific growth processes may be investigated.

Bacterial calorimetry is not new. Recently W. W. Forrest ${ }^{1}$ has done a thorough review on the status of bacterial calorimetry up to 1969. Bacterial thermogenesis had been studied earlier by a number of biochemists: Bayne-Jones and Rhees ${ }^{2}$, Peters on and Wilson ${ }^{3}$, Carlyle and Norman ${ }^{4}, \operatorname{Rahn}^{5}$, and Stoward ${ }^{6}$. In 1963 Prat $^{7}$ applied modern calorimetric techniques to bacterial studies and showed that the behavior of microbial systems gave reproducible thermal patterns of growth.

Quantitative studies were shown to be practical for both growing and non-growing bacteria, by Battley ${ }^{8}$, Forrest et $\underline{a l}^{9}$, Belaich ${ }^{10}$, and Boivinet $^{11}$.

According to Forrest ${ }^{1}$, there are various factors which influence the heat generated by bacteria. Generally, these can be summarized under two broad headings: (A) Growing cells in pure culture, and (B) Nongrowing cells in pure culture.

A. Growing ce11s

A standard text which summarizes the extensive literature concerning behavior of bacteria is Lamanna and Mallette ${ }^{12}$. 

According to Forrest, initially there is usually a lag phase, after which, the rate of heat generation increases exponentially as the cells begin to divide. This exponential growth is limited by the energy source. A very good correlation has been obtained ${ }^{10,11}$ with the enthalpy change calculated for the degradation of substrate to the observed products, after allowing for second-order effects such as heats of dilution, neutralization, etc. Forrest ${ }^{1}$, based on works by Wilkie ${ }^{13}$ and Prigonine ${ }^{14}$, stated that while a calorimeter, in principle, can detect coupled anabolic reactions, it is not practical to determine the enthalpy of growth as it would be expected to be less than the experimental error of the calorimetric measurement. However, the use of newer microcalorimetric techniques may make enthalpy of growth determinations more practical in the future.

When growth is limited by specific nutrients, heat evolution is observed at a low level and appears to be limited by a specific constituent of the medium or an accumulation of toxic products or both.

In addition to heat being evolved from cell division, heat is produced as the cells metabolize, usually during the period immediately following the exponential growth. Reserve materials such as ATP (Daves and Ribbons ${ }^{15}$, Hungate ${ }^{16}$ ) may be accumulated during the latter period and heat production subsequently may occur from the degradation of these reserves. This endogenous metabolism tends to last for long periods of time (Siga 1 et $\underline{\text { a }}^{17}$ ). 



\section{B. Non-growing cells}

In many cases with aerobic bacteria, where respiration occurs, the metabolism may be followed by a manometer, but in the case of anaerobes there is no readily measurable change.

The bacterial Streptococcus faecalis is an example of an anaerobic organism which shows no $\mathrm{pH}$ change in the medium and no detectable respiration, but a substantial enthalpy change was observed calorimetrically by Forrest and Walker ${ }^{18}$.

Many studies have involved non-growing or resting cells because of the absence of the complications of growth and cell fission. In this manner, relationships have been shown for $\underline{\mathrm{S}}$. faecalis grown in a medium with excess energy source which allows an accumulation of reserve materials such that they could carry on endogenous metabolism in the resting state. This feature has been contrasted with organisms which possess no detectable endogenous enthalpy change when grown in a limited energy source (Forrest and Walker ${ }^{19}$ ).

This report summarizes the results of some exploratory bacterial growth experiments conducted at the National Bureau of Standards with the new NBS Clinical Microcalorimeter ${ }^{22}$. We wish to thank Ms. S. Farling and Dr. W. Russel1 of the Instrumentation Laboratory, Inc., Lexington, Massachusetts 02173 for supplying the bacteria and cultures and assisting in the conduct of the experiments. 



\section{Instrumentation}

The microcalorimeter used in this investigation was designed and constructed at the National Bureau of Standards and will be described in detail in NBS Report ${ }^{22}$.

The calorimeter is a heat conduction microcalorimeter utilizing commercially available heat flow discs. The inner chamber which surrounds the block is thermostated and the temperature of the block is thus passively controlled. The reaction cells are able to be placed in the block and can be removed from the block easily.

The details of the instrumentation and automatic digital data acquisition system have already been discussed ${ }^{21}$ in the National Bureau of Standards Report No. 10437.

Briefly, the output of the thermopiles contained in the microcalorimeter is followed by a precision nanovolt amplifier as a function of time. This signal is amplified by a factor of $10^{5}$ and digitally recorded on punched paper tape. This teletype tape is then processed in a computer to produce a digital record which can be plotted. This was done to produce the figures illustrated in this Report.

Small plastic vessels of a capacity of about $0.4 \mathrm{ml}$ are used to contain the material for insertion between the thermopiles of the microcalorimeter. The inside cell thickness is $2.5 \mathrm{~mm}$. The calorimeter has a fast response time (half-time of 30 seconds). 



\section{Experimental}

\section{A. Cell disinfection}

Clean cells were rinsed 3 or 4 times with "Amphyl" disinfectant, then rinsed 6 times with sterile distilled water.

\section{B. Preparation of Inoculum}

A small amount of growth from the stock culture was placed in $5 \mathrm{ml}$ of brain-heart infusion broth using a platinum loop that had been sterilized by flaming in a Bunsen burner.

This inoculum was incubated for 4 or 5 hours at room temperature, at which time the brain-heart infusion had become cloudy.

Using sterile pipets, a dilution of 1:500 of this culture was made in the brain-heart infusion.

About $4 \mathrm{ml}$ of brain-heart infusion was the inoculated using one loopful of the above 1:500 diluted growth. Only about $0.4 \mathrm{ml}$ of this final dilution was used to fill the cell which was inserted into the microcalorimeter. The inside cell thickness is $2.5 \mathrm{~mm}$.

\section{Data Acquisition}

The output of the thermopiles of the microcalorimeter was followed as a function of time. Readings of time and voltage were made every 30 seconds over a period of 14 to 24 hours for each growth study. The data were taken and plotted in digital form to produce the figures discussed in the following section. 

4. Results and Discussion

Three bacterial growths were run in duplicate. These bacteria were

(1) Enterobacter cloacae,

(2) Proteus rettgeri and

(3) Klebsiella

pneumoniae. Each growth study was monitored by the automated data acquisition system.

The Enterobacter cloacae thermograms are shown in Figures 1 and 2. Figures 3 and 4 illustrate the heat production from the growth of Proteus rettgeri and Figure 5 shows the thermal growth pattern of Klebsiella penumoniae. Only one run was obtained on the latter.

As can be seen by comparing the figures for each pair of thermal growth patterns (Figs. 1 and 2 are superimposed in Fig. 6. Figs. 3 and 4 are compared in Fig. 7), a reproducible pattern is observed between duplicate runs. Most of the significant features are duplicated. Furthermore, the high sensitivity of the microcalorimeter enables one to discern much finer details in the "fingerprint" of each bacterial growth than had been observed even in the most recent investigation ${ }^{20}$. Due to the short sampling time used and the rapid response time of the calorimeter, changes in metabolism could be observed (Fig. 1, 2, 3) almost instantaneously. Cessation of heat evolution was observed to occur within a 30 second time lapse in some cases (Fig. 8). Figure 8 is an enlargement of the early portion of Fig. 4. In Fig. 8 the instantaneous halt in the production of heat was observed which lasted for a period of 3-5 minutes. 

These results indicate a possible means of identification for a large number of microorganisms routinely determined to clinical laboratories $^{20}$. The rapidity of measurement appears to have a great advantage over present methods.

For research laboratories, the kinds of valuable information which may be gleaned from such microcalorimetric measurements could include the determination of metabolic levels of activity, comparative studies of microbial metabolism, determination whether a postulated reaction occurs, detection of unknown reactions, interpretation of mechanisms of growth (especially in complex mixtures such as natural systems) and a possible means of identification of a variety of strains of the same microorganism. 

[1] Brown, H. D., ed., "Biochemica1 Microcalorimetry", Academic Press, New York, (1969).

[2] Bayne-Jones, S., and Rhees, H. S., J. Bacteriol. 17, 123, (1929).

[3] Peterson, W. H., and Wi1son, P. W., Chem. Rev. 8, 427, (1931).

[4] Carlyle, R. E., a nd Norman, A. G., J. Bacteriol. 41, 669, (1941).

[5] Rahn, 0., "Physiology of Bacteria", McGraw-Hil1 (Blakiston), New York, (1932).

[6] Stoward, P. J., Nature 194, 977, (1962).

[7] Prat, H., In "Recent Progress in Microcalorimetry" (H. A. Skinner, ed.), pp. 111-174, Pergamon Press, London, (1963).

[8] Battley, E. H., Physio1. Plantarum 13, 192, 628, 674, (1960).

[9] Forrest, W. W., Wa1ker, D. J., and Hopgood, M. F., J. Bacteriol. 82, 685, (1961).

[10] Belaich, J.-P, Compt. Rend. Soc. Bio1. 157, 316, (1963).

[11] Boivinet, P., Ph.D. Thesis, Univ. of Marseilles, (1964).

[12] Lamanna, C., and Mallette, M. F., "Basic Bacteriology", Williams and Wilkins, Ba1timore, (1959).

[13] Wilkie, D. R., Progr. Biophys. Biophys. Chem. 10, 259, (1960).

[14] Prigogine, I., "Thermodynamics of Irreversible Processes", p. 27 Wiley (Interscience), New York, (1961).

[15] Dawes, E. A., and Ribbins, D. W., Bacteriol. Rev. 28, 126, (1964).

[16] Hungate, R. E., J. Bacterio1. 86, 848, (1963).

[17] Siga1, N., Cattaneo, J., and Segal, I. H., Arch. Biochem. Biophys. $\underline{108}, 440,(1964)$. 

[18] Forrest, W. W., and Wa 1ker, D. J., Biochem. Biophys. Res. Commun. $13,217,(1963)$.

[19] Forrest, W. W., a nd Walker, D. J., Nature 207, 46, (1965).

[20] Boling, E. A., Blanchard, G. C., and Russe11, W. J., Nature 241, , (1973).

[21] Goldberg, R. N., Nutta11, R. L., Prosen, E. J., a nd Brunetti, A. P., National Bureau of Standards Report No. 10 437; Digital Data Acquistion and Computer Computation Applied to Calorimetric Experiments, (1971).

[22] Prosen, E. J., National Bureau of Standards Report 73-179, April 1973. 
. 


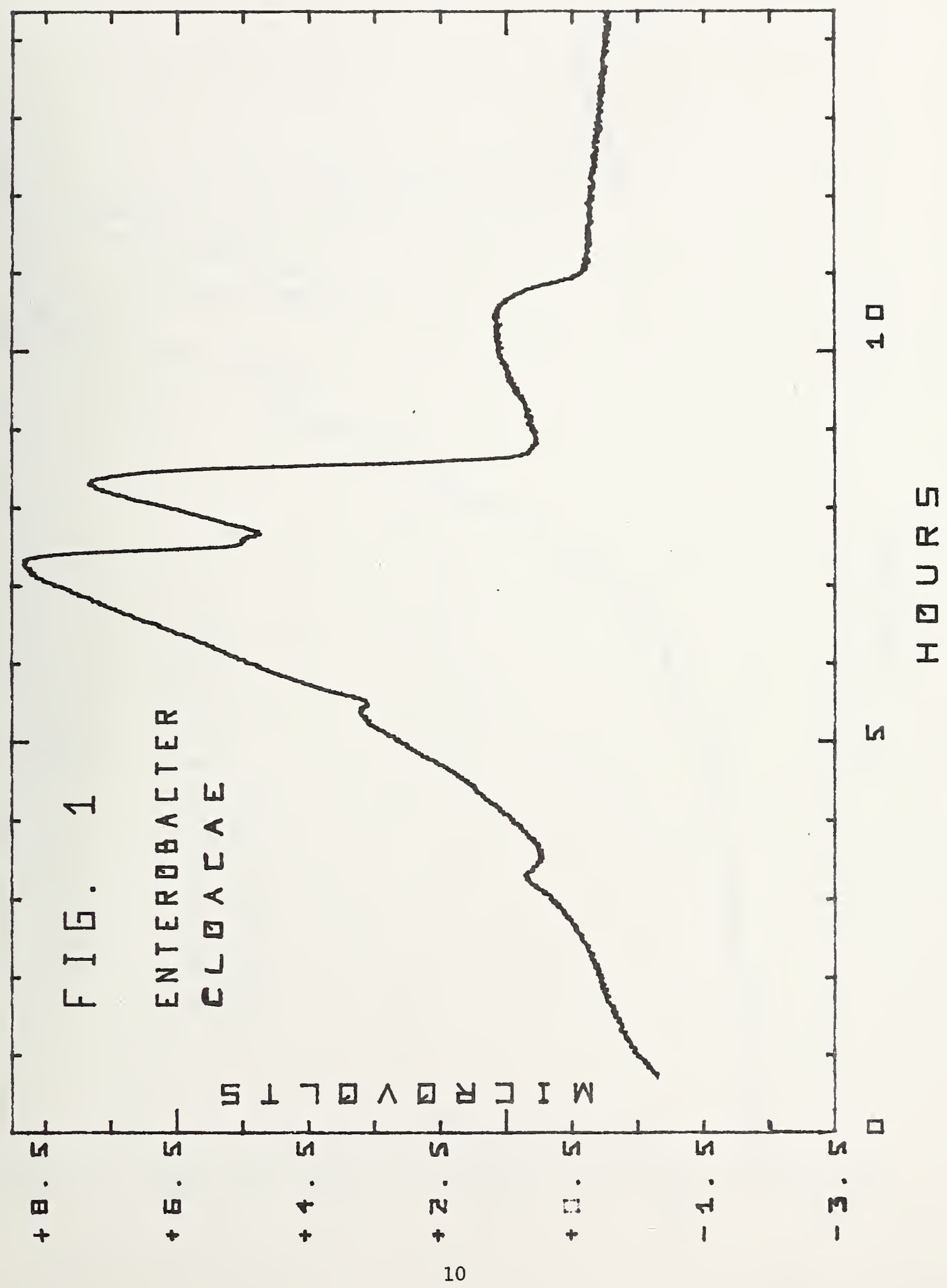





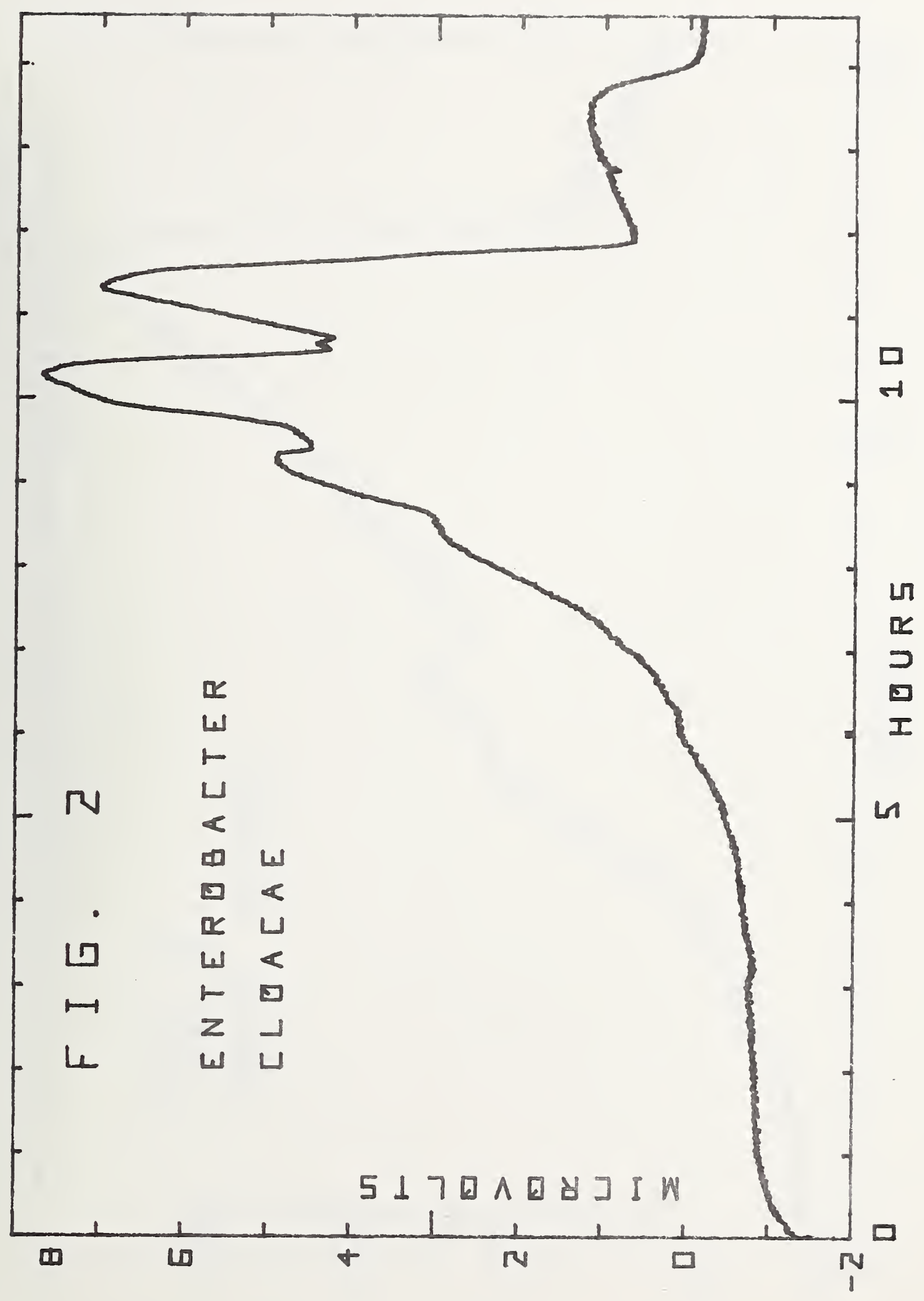





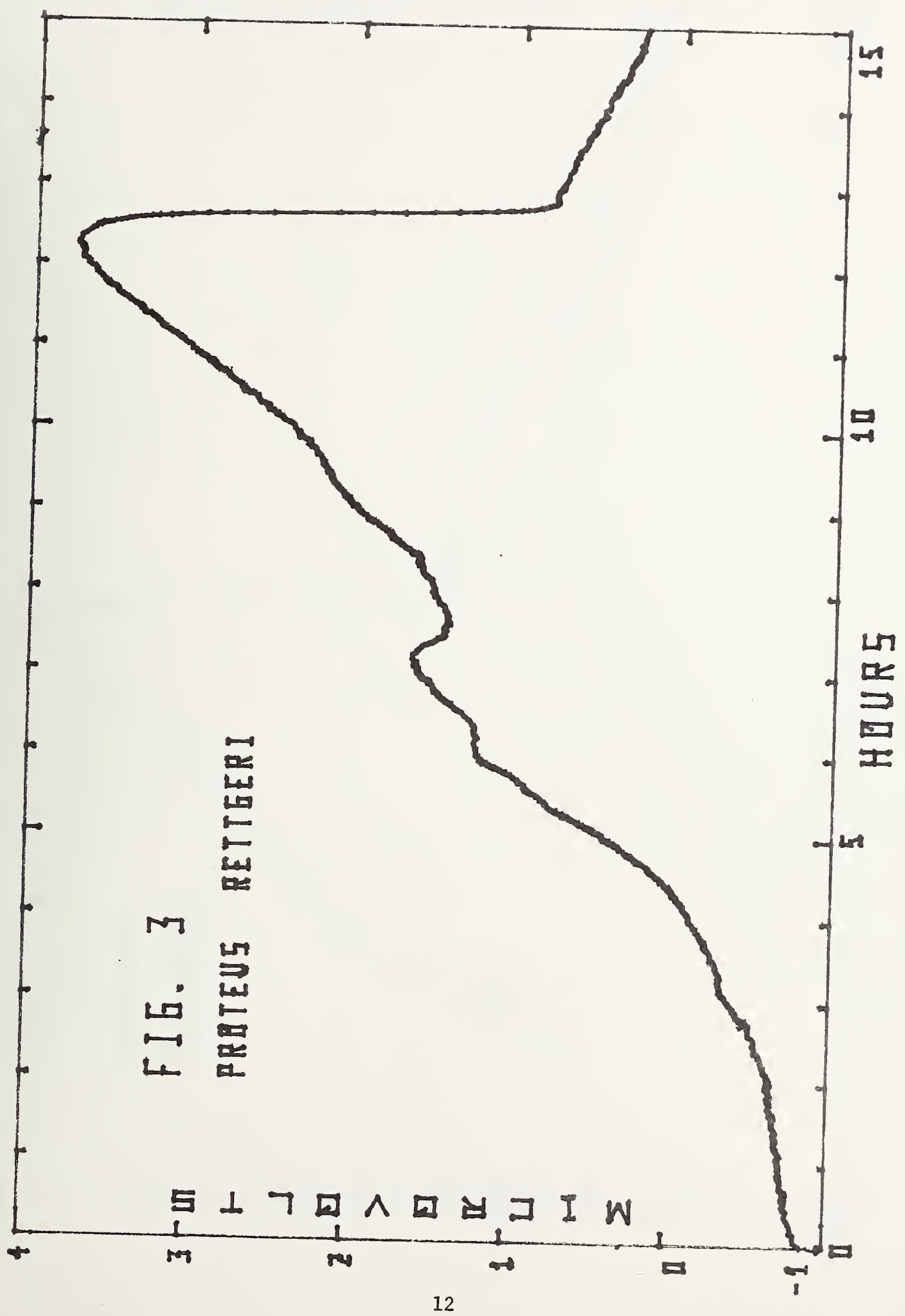





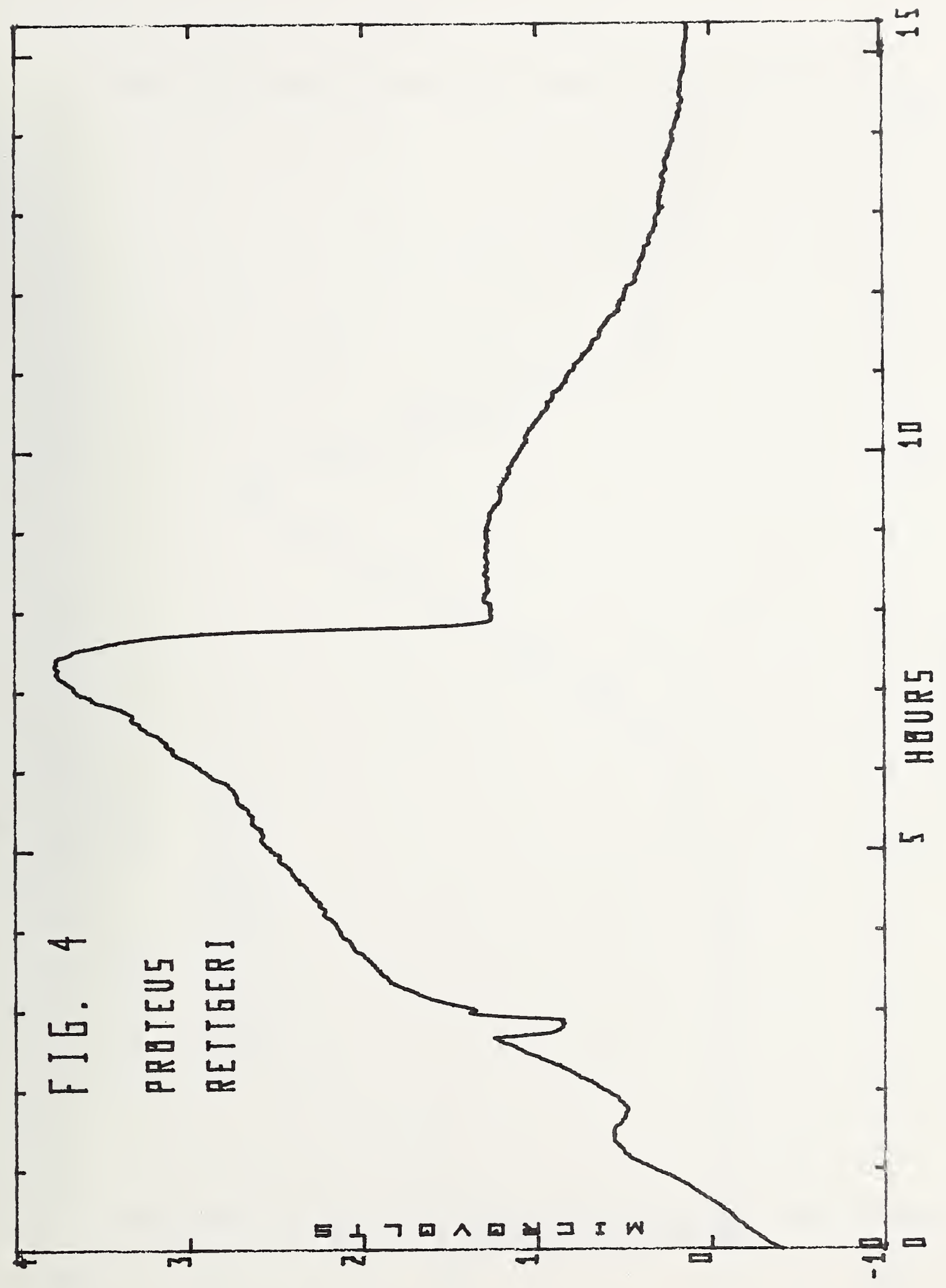





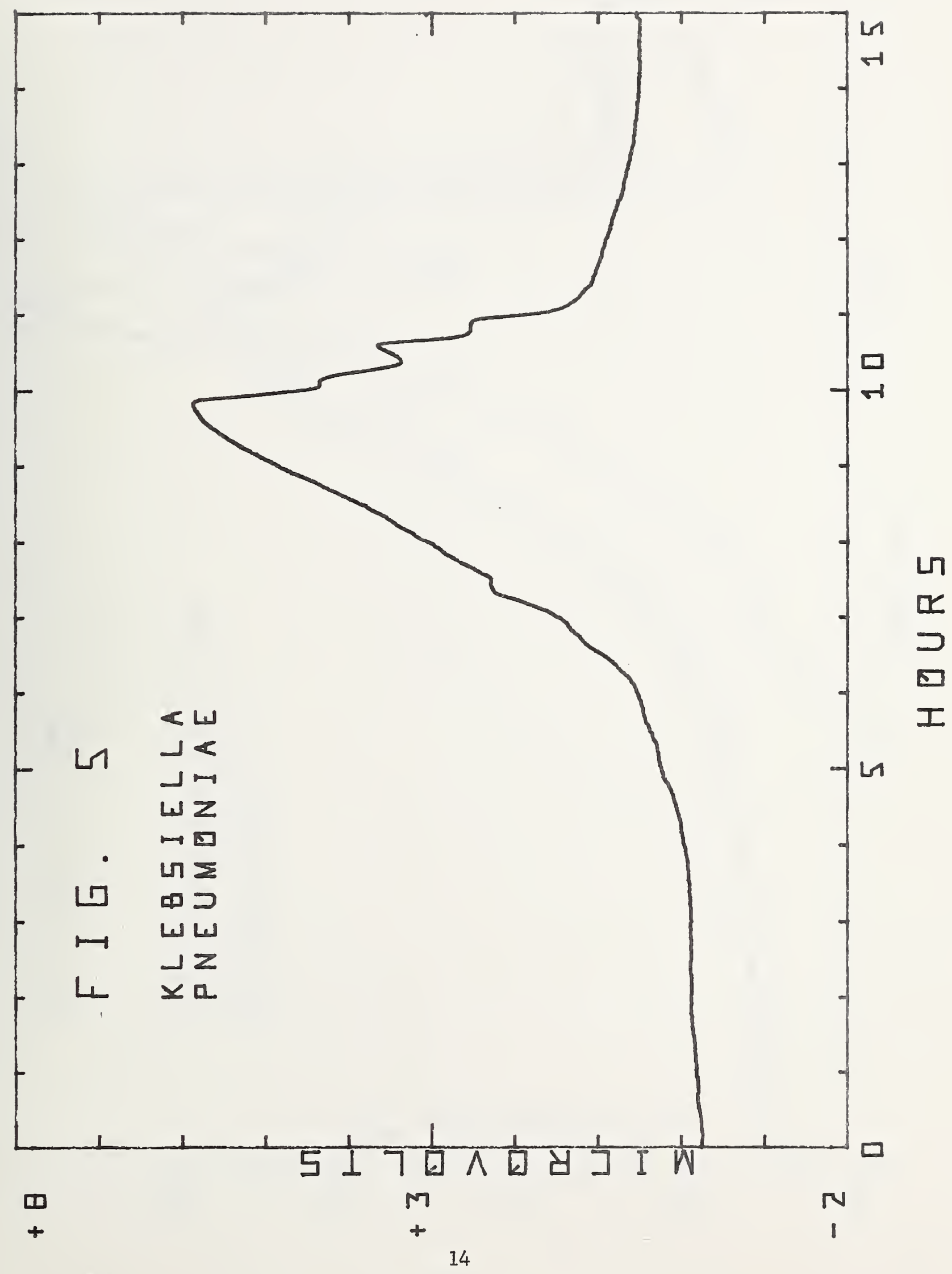





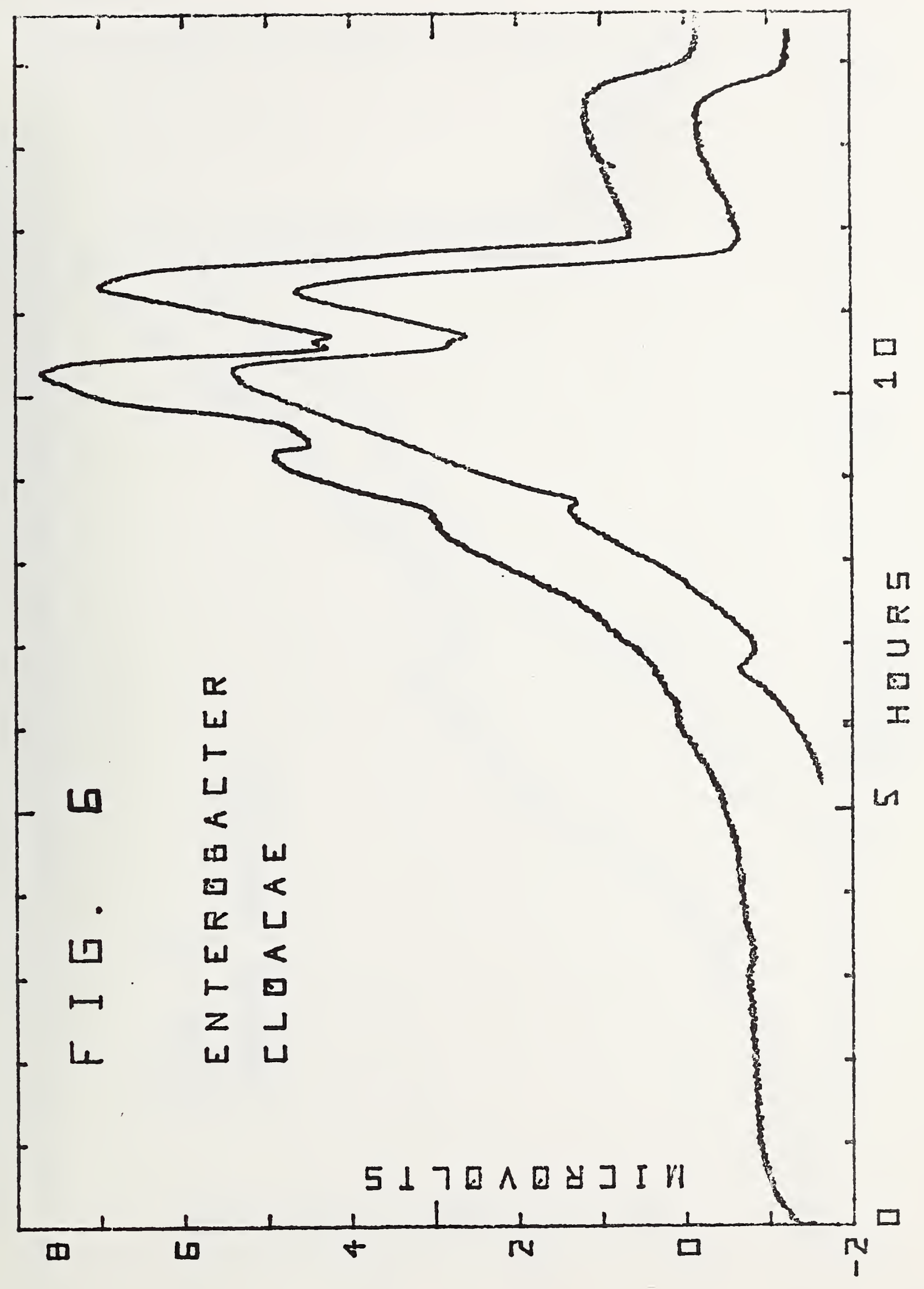





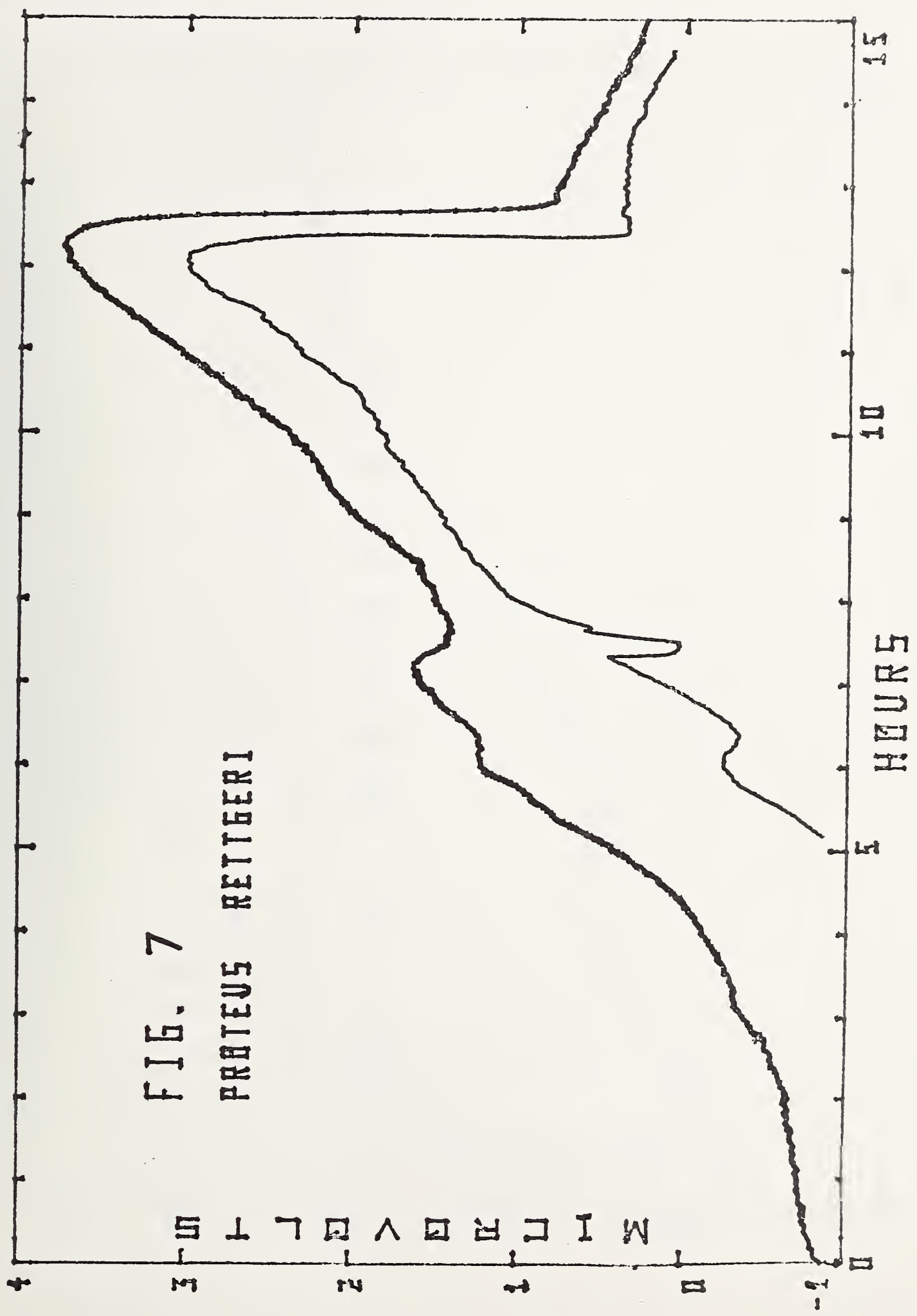





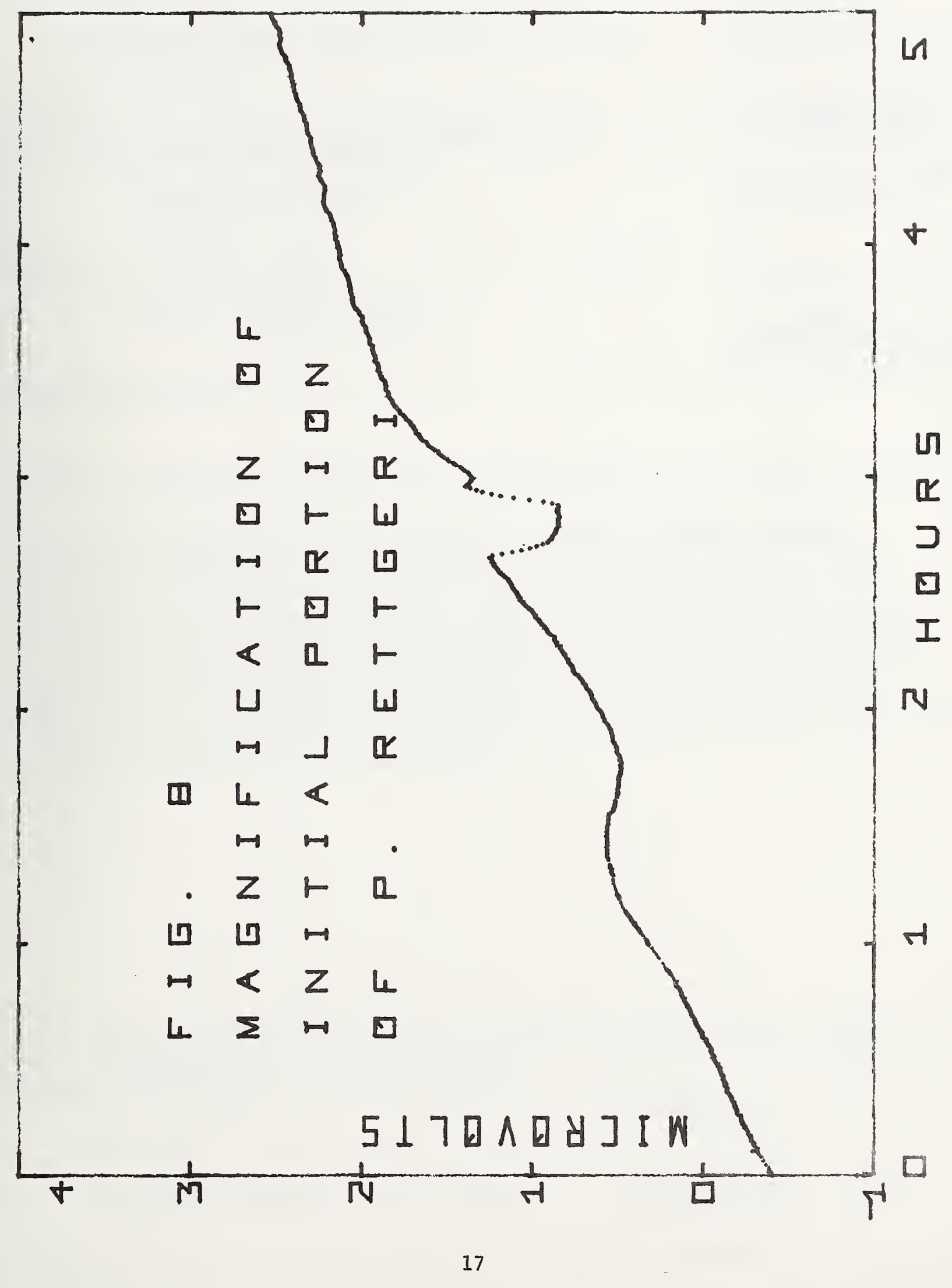





\begin{tabular}{|c|c|}
\hline $\begin{array}{c}\text { U.S. DEPT. OF COMM. } \\
\text { BIBLIOGRAPHIC DATA } \\
\text { SHEET }\end{array}$ & $\begin{array}{c}\text { 1. PUBILICATION OR REPORT NO. } \\
\text { NBS IR } 73-181\end{array}$ \\
\hline
\end{tabular}

4. TITLE AND SUBTITLE

Fine Structure in Thermal Growth Patterns of Bacteria by Microcalorimetry

7. AUTHOR(S)

Staples, B。R。, Prosen, E. J., and Goldberg, R. N.

9. PERFORMING ORGANIZATION NAME AND ADDRESS

NAT IONAL BUREAU OF STANDARDS

DEPARTMENT OF COMMERCE

WASHINGTON, D.C. 20234

12. Sponsoring Organization Name and Address

National Institutes of Health

Bethesda, Maryland 20014
2. Gov't Accession 3 3. Recipient's Accession No. No.
5. Publication Date

Apri1 1973

6. Performing Organization Code

8. Performing Organization NBSIR 73-181

10. Project/Task/Work Unit No.

316-0118 and 316-0411

11. Contract/Grant No.

13. Type of Report \& Period Covered

Interim

14. Sponsoring Agency Code

15. SUPPLEMENTARY NOTES

16. ABSTRACT (A 200-word or less factual summary of most significant information. If document includes a significant bibliography or literature survey, mention it here.)

Thermal growth patterns of Enterobacter cloacae, Proteus rettgeri, and Klebsiella pneumoniae have been determined with the new NBS Clinical Microcalorimeter. These patterns show more fine structure than those made by previous calorimeters. This is due to the much faster time constant (halftime 30 seconds), the use of smaller volumes $(0.4 \mathrm{~m} 1)$ or thicknesses $(2.5 \mathrm{~mm})$ of samples, and the high sensitivity of the NBS Microcalorimeter. Furthermore, this fine structure is shown to be reproducible and thus is valuable for finer bacterial "fingerprinting" or identification than was previously available. The simplicity of the apparatus and the ease of insertion of samples and operation of the calorimeter make this method attractive for possible routine use in detection and identification of bacteria.

17. KEY WORDS (Alphabetical order, separated by semicolons) Bacterial growth; bacterial detection by microcalorimetry; bacterial thermal growth patterns of bacteria; fine structure of bacteria 1 ; identification by microcalorimetry.

\section{AVAILABILITY STATEMENT}

UNL IMI T ED.

FOR OF FICIAL DISTRIBUTION. DO NOT RELEASE TO NTIS.
19. SECURITY CLASS (THIS REPORT)

UNCL ASSIF IED

20. SE CURITY CLASS (THIS PAGE)

UNCL ASSIFIED
21. NO. OF PAGES

22. Price 

